\title{
Why is there no Socialism in Europe? The Technocratic Neoliberal turn in European Economics
}

\author{
Steven Colatrella \\ University of Maryland \\ University College and Boston College in Parma
}

The neoliberal turn in European economics was not largely the work of economists, but of technocrats in finance ministries and central banks. Governments accepted their lead, responding to the loss of relative power to electorates and to organized labor. Politicians sought solutions to problems of economic management arising from the end of the Bretton Woods system of fixed exchange rates and from the Oil Crises of the 1970s. But in siding with technocrats informed by monetarist and neoliberal economists' arguments, and in ceding to central bankers especially control of economic policy and EU negotiations over the Euro, politicians opened the door to increased power in the hands of mobile capital allied with technocrats in Finance Ministries and Central Banks. The most that can be said of economists as a profession is that they went along for the ride, happy with a new situation that celebrated their importance as consliglieri to the powerful.

\section{What Happened?}

Just a few years ago, the European Union seemed a practical, one might even say "Actually Existing" alternative to the neoliberal, free market-obsessed, compassionless US version of capitalism. Jeremy Rifkin wrote "The European Dream", Mark Leonard, "Why Europe Will Run the $21^{\text {st }}$ Century", and Susan George in her book "Another World Is Possible, If..." included as one of the "ifs" that the book is organized around "If Europe Wins the Battle of the West".

Today, the EU is in crisis, as one nation after another is led by nationalist governments that are skeptics, and sometimes opponents of the Euro and even of the EU itself. Worse, the rise of authoritarian, racist, sexist right wing governments is at least in large part a reaction to the post-2008 economic policies of the EU imposed on member states. Notwithstanding infrastructure spending by the EU, the dominant policies have been low-growth, neoliberal market orientation, privatizations, austerity and liberalization of labor markets and reduction of pensions and social programs. Europe is no longer an alternative to the neoliberalism that has swept the world, nor to US priorities. Indeed, it is not only a bulwark of neoliberalism but is increasingly under pressure from right wing, even neo-fascist forces that are both a logical result of, and paradoxically a protest against, the sway of neoliberalism.

How did this happen? How could a continent of social market economies, welfare states and social democracy, the birthplace of modern socialism, where working class fidelity to socialist principles seemed rock solid even a few years ago, have become a world bereft of socialist aspirations, where the only debates seem to be about how most efficiently to eliminate every welfare state and labor guarantee? How has low growth, high unemployment, indeed Depression-era unemployment rates for young people, 
become acceptable politically and economically, and remained so despite all evidence, contrary opinion, protest, resistance? Why is there no socialism in Europe?

This question, and the title of this paper, of course both echo and paraphrase, and give an ironic twist to Werner Sombart's classic thesis "Why is there no Socialism in the United States"2. For Socialism was understood to be a European norm, one which the US was largely immune to due to its lack of a feudal past (Sombart), its universally-accepted liberalism (Hartz), its frontier (Turner) ${ }^{3}$, or the availability of cheap land and the Jeffersonian ideal, or later of the hegemonic and prototypical "rugged individual" qua entrepreneur. Today, it is not at all implausible to understand the European experience as attempting to reproduce American conditions in Europe itself. And certainly the economics profession has become an extension of American neoliberal economics in universities throughout the continent. In turn, those trained in such economics departments and in business management programs throughout Europe have taken the assumptions of neoliberal economics as their worldview, translating it into policy. The EU institutions have acted as the privileged and central advocate imposing neoliberal norms well beyond the immediate business world, and the Central Banks of the EU member states have been the main executive committee for the management of the affairs of neoliberal economics across Europe. But the neoliberal turn in European economics did not start with economists, nor have they been the primary advocates, initiators, nor even the heralds of the new and distorted order of European economics.

\section{The Economists Went Along for the Ride}

The first thing to note is that there was never a neoliberal consensus over economic policy among economists in any European country before the fact, that is, before the early 1980s, and the double watershed of Margaret Thatcher's reign in Britain and Francois Mitterand's right turn away from his initial socialist-oriented reforms, the former taking power in 1979, the latter in 1981 but changing course dramatically in 1983. There were already in place before that neoliberal elements in policy-making to a degree that had been unnoticed until recently. For example, the Labour governments in Britain already had adopted many elements of monetarism by 1974, and the Giscard D'Estaing presidency in France had adopted austerity already in those same years.

And there had been a few key centers of neoliberal economic thought, such as at the major eliteproducing universities in France, in some British departments, and here and there throughout the continent. Others moved in that direction under the influence of the Thatcher-era experience in Britain, notably in Poland where under martial law the intellectuals allied with the Solidarity movement, both in and out of the organization KOR (workers defense league) left its worker-control ideology for reforming socialism and moved toward a noliberal, market and privatization oriented direction. ${ }^{4}$

\section{The Actors}

But it is to some other places, far from academia, that we must look for the real sources of the neoliberal agenda taking hold in Europe: to the first meetings in Davos in 1971, when it was called the European Management Symposium and pioneered, according to Saul, "viewing society through an economic prism" to the first G7 meetings; to the EU negotiations over the Maastricht Treaty and over the Euro; and to the key role of Central Bankers, Finance Ministers and technocrats, some of whom later became heads of governments.

There are several sets of key actors whose roles in the neoliberal turn in Europe we must decipher: technocrats, including Central Bankers, Finance Ministers, and the bureaucratic authorities of international organizations like the EU Commission and the International Monetary Fund; elected officials; capitalists - by which I mean investors and financiers whose principal objective is to convert a sum of invested or loaned money into a greater sum of money by seeking the highest available profit rate $^{6}$, and are not content to merely re-invest in the same enterprise or activity even if profitable if greater profits can be found elsewhere; and economists as a profession.

While the importance of each of these different sets of actors varied country by country and over time between the 1970s and today, I have more or less listed them in order of importance in the process of shifting policy over these past decades from Keynesian growth and full employment or Social 
Democracy, to neoliberal norms and economic mandates, including the post-2008 austerity policies that have brought the EU to the brink of ruin. If I am right, we see here that classical Marxist notions of the relationship of actors to one another need to be rethought in light of the experience in Europe. This experience has been distinct from that in the US and UK, which will be dealt with here, but as somewhat anomalous. For in the US and to a lesser extent in the UK, capitalists as an organized force, organized as a class in classical Marxist terms, played arguably a leading (in the US, after the Powell Memo as John McDermott's companion paper in this Conference workshop makes clear ${ }^{7}$ ), or a partner (in the UK) role based on direct class struggle between capital and labor. But on the Continent the role of capitalists as investors and financiers was two-fold: a) it was opportunist, taking advantage of opportunities provided by shifts in policy or in policy perspective, and b) it exercised, through what Ralph Miliband called "class power" - control of investment - a veto power over policies that were unacceptable to capitalists, usually by leftist or left-leaning governments.

We need to investigate the motivations of each of these particular actors to better understand how the extraordinary shift in emphasis and priorities in Europe has taken place.

First, the role of technocrats has been central. As we have seen, economists as a profession were not particularly neoliberal in the 1970s in Europe, though the award of the Nobel Prize for Economics to Milton Friedman was an early sign of a change in viewpoint. But technocrats, such as Valery Giscard D'Estaing were essential to changing direction. As William Mitchell and Thomas Fazi show in Reclaiming the State ${ }^{9}$, the traditional struggle between policymakers in the French planning ministry and technocrats in the finance ministry saw D'Estaing among the latter. The technocrats, unlike elected leaders (excluding Thatcher and Keith Joseph's wing of the British Tories), and economists, were "increasingly absorbing the monetarist doctrine). Upon his election as President of France in 1974 he already initiated, well before Margaret Thatcher's government in the UK, "the world's first real monetarist experiment" - imposing austerity through the Barre plan, named for his own Finance Minister Raymond Barre. ${ }^{10}$ D'Estaing had company: the Bank of England had fully embraced monetarist doctrine as early as 1968, rejecting the Radcliffe Report, the 1959 study that had guided British fiscal and monetary policy up to that point. And while the influence of Milton Friedman was still limited among economists and not yet central to most politicians of any British party (again the Thatcher-Joseph wing of the Tories being the exception and still years away from power), after his March 1968 Presidential Address to the American Economic Association was "widely covered" in the British financial press, and following the collapse of the fixed-exchange rate system in 1971, this influence was growing in importance among business leaders, particularly in finance. As Aled Davies shows, investors began to use the money supply as a convenient new measure for judging the soundness of government policies. ${ }^{11}$ The implicit alliance between technocrats, capitalists and neoliberal economists was already present at the IMF meetings with the British government in 1968 that featured only discussion of monetary policies. With business beginning to insist on monetarist standards in government policy, as Davies quotes Peter A. Hall, " "many of the ad hoc adjustments towards monetarism made by the 1974-79 Labour Government were forced on it by the behavior of the financial markets, and the popularity of monetarist doctrine in these markets influenced both the Bank of England and the Government. ${ }^{, 12}$

Here we see the direct class power of capitalists acting to pressure governments as early as the mid1970s, well before the Reagan-Thatcher turn and before any general shift in public opinion, even of elite publics, toward neoliberalism. Keynesian doctrines, even if as tamed and amended by Samuelson and Cold War militarism, remained dominant intellectually and among elected officials until the early 1980s even in the US and UK. But this class power was first of all itself dependent first on contingent events the collapse of Bretton Woods fixed exchange rates following the rise of the Eurodollar market and the US war in Vietnam that went un-financed by tax increases; second, it needed in any case to be mediated by technocratic power and influence - its influence was through Central Bankers and Finance Ministers, and through these eventually reached elected officials and government policy. Only after being adopted whole-heartedly by technocrats and by governments even if ambivalently, did it become accepted wisdom in economics classrooms outside of the few outliers mentioned earlier. In the last 1970s, the Labour government accepted ceding control of the money supply to the Bank of England as a concession 
demanded by the IMF. Elected governments bent to the will of mobile capital (to use Max Weber's phrase $^{13}$ ) only when technocrats both international and national demanded it of them.

What then is the motivation of this group of actors that find no place in modern political science doctrines, be they liberal pluralist, modern republican (what branch of government in James Madison's scheme of checks and balances is the Federal Reserve?), or Marxist? As with any group of political actors, their interest lies in furthering and strengthening policies, institutions, outlooks, and norms that enhance their own influence and power relative to the influence and power of other actors. The monetarist turn, and neoliberal norms, institutions and policy-making structures favor the interests of technocrats as an interest group in themselves. Here interest must be understood politically - as always a relative question, compared with the interests, influence and power of competing groups. Before the neoliberal hegemony, during the Keynesian-Bretton Woods period, in the postwar democracy and Social Democratic experiments from the 1950s to the 1970s, technocrats in corporate and governmental bureaucracies, in state and private financial institutions, and in international organizations were not as influential as labor unions, working class political party constituencies, electorates and elected officials . The more central role of the Marshall Plan in rebuilding the infrastructure of postwar Europe instead of the World Bank is an example of this dominance of public officials rather than technocrats. That such a major project which would seem well-adapted to the skill sets of technicians, engineers and technocratic planners was largely guided by policies of elected governments gives a sense of the relative marginalization of technocrats in the postwar democratic order.

Yet certainly Keynesian economics and especially the Soviet version of state run economies had a role for technocrats. Indeed, it is possible that the technocratic element of New Deal and European Social Democratic economics, and of Soviet bureaucracies was a major cause of these otherwise popular policies losing public support. That said, in each of these systems, it was elected politicians who governed, and technocrats were merely advisors. The difficulty faced by US President Kennedy's economic advisors to get him to see the economy as they saw it, and their celebration at his Yale University speech embracing a largely technocratic view of economics (though with a lack of genuine enthusiasm evident in his delivery) is testimony to this distance between politicians and their advisors. In Gaullist France the role of technocrats was always likely to be considered more legitimate, tracing its ancestry all the way to the $18^{\text {th }}$ Century Enlightenment. Arguably it went even further back to Descartes' development of a non-local, anti-particular context, ahistorical vision of rationalism ${ }^{14}$. But in Britain and the US, with their liberal and Common Law heritages, and empirical intellectual traditions, technocracy was always viewed with some suspicion. In Italy and Germany Keynesian policies were never really adopted as the official guide to economic management.

More to the point, politicians running economic and social policy meant electorates, and therefore interest groups in society and most significantly of all, organized labor, having a major voice in the formulation and implementation of economic and social policy. This was anathema to technocrats and remains so. ${ }^{15}$ The neoliberal bias against popular input into the supposedly technical aspects of economic policy-making and the need for expertise in determining the direction of society meant first and foremost to expel labor unions and working class parties with strong presences of organized workers from policymaking. This natural opposition between organized labor as a major popular class interest group representing and mobilizing the preferences of the democratic electorate, indeed as a stand-in for the demos, and technocratic expertise, leads us to ask why elected officials would side with the latter over the former when the going got tough.

If again, we take as a generic hypothesis that all political and social actors seek to hold influence and power in their own individual, organizational, network, class or institutional structures, and so are jealous of other centers of power and influence, we find that notwithstanding the ideological affinity that many left-leaning governments and parties may have had with organized labor and with working class networks in general, that the power and influence of organized labor had come to seem an alternative and rival center of power to many even on the left, and certainly to governments, leaders and parties of the right. The 1970s saw not only a consolidation of many gains that unions and workers had fought for and won previously, but in diverse forms, saw also an expansion of the ambitions of working class movements that 
challenged the monopoly of governments and of the management of companies to actually manage and govern. ${ }^{16}$ In Britain the strike waves of 1974 and 1979 (the so-called "Winter of Discontent") showed the ability of workers, especially miners to veto government policy and bring down governments themselves. In Italy, strike waves and factory occupations had severely challenged the ability of company management to govern their own workplaces. The struggles in Italy led to an indexing of national wage rates to the inflation rate as well. In Sweden a proposed law would have gradually transferred ownership of the majority shares in Sweden's large companies to workers and unions. German unions proposed extending co-determination rights to worker representation to one half of company boards. In Portugal workers control of factories and fields became common during that country's 1974 revolution, and in a precursor of what was to come in the rest of Europe, the Socialist Party began to move against selfmanagement as a threat to central power. In Poland in 1981 the Solidarity movement called for the socalled "Active Strike" - shutting down workplaces to then reopen them under workers' management.

In the face of these expansions of workers and union power, and challenged by the end of the Bretton Woods fixed exchange rate system, the energy crises and a growing restlessness by investor and finance sectors, governments began to shift emphases from Keynesianism and Social Democracy and to listen to the technocrats who, in turn, informed by the increasingly vocal monetarist economists, advised a shift in policies and in institutional structures. Thus, for example, economists Franco Modigliani and future center-left finance minister Tommaso Padoa-Schioppa argued that the $100 \%$ wage indexing provision in Italy would raise labor costs in a controversial 1977 paper. ${ }^{17}$ Already the British Labour government had adopted the money supply as the key indicator to guide monetary and fiscal policy.

Finally, the motivations of capitalists qua investors and financiers are the easiest to divine thanks to the work of Karl Marx, Max Weber, Adam Smith, Thorstein Veblen and Joseph Schumpeter, and Karl Polanyi, among others. A capitalist is one who seeks to transform a sum of money capital M by investing it into some process or activity that takes the form of a commodity (something to be bought and sold), leading to a larger sum of money capital M' at the end of the investment cycle. This concern precludes any loyalty or commitment to re-investing in the same sector, enterprise or activity, or even in the same country or society, even if these sectors remain profitable and sustainable economically, if greater profit rates on investment or finance are available elsewhere or under different conditions. The Bretton Woods system of capital controls and fixed exchange rates had, following implicitly the advice of Polanyi and Keynes, placed limits on the mobility of capital. And while the GATT negotiations had gradually reduced tariffs, protectionism had remained the rule and not the exception during the pre-neoliberal era, again reducing the freedom of investment into the most profitable sectors globally that free trade permits.

\section{The Turning Points}

In 1979 Margaret Thatcher came to power in Britain, and a year later Ronald Reagan won election to the Presidency of the United States. The latter result led to the firing of most Keynesian economists from the IMF, with Chief Economist Anne Kreuger taking charge and moving the IMF toward neoliberal orthodoxy. But Reagan's election was followed hard on its heels by the victory of Francois Mitterand as President of France. As is well known, Mitterand's combined Keynesian-Social Democratic and Socialist program was confronted by 1983 with a massive capital flight from the country, and he turned domestically in a neoliberal direction, privatizing, deregulating, closing factories and imposing austerity. But at the same time, he sought in the negotiations over European integration to enlarge the playing field, hoping that what France could no longer do alone - deal with mobile capital on an increasingly international scale, Europe as a whole could. ${ }^{18}$

But the EU negotiations took place under different circumstances than had those leading to the Bretton Woods system. In the former case private capitalists were largely de-legitimized by the Great Depression and in many cases by their collaboration with Fascism and Nazism which were themselves seen to be results of the failure of market capitalism. In the case of what became the Maastricht negotiations that led to the Single European Act and the creation of the EU, it was the roles of organized

labor, of working class militancy, of Keynesian solutions, of fiscal instead of monetary policy, of fixed exchange rates, and of elected party politicians and the processes they governed through that seemed to be 
delegitimized. The capital flight disciplining of the Mitterand Government, and the exemplary lesson of Thatcher's defeat of the Miners' Strike in Britain in 1984-85, and the speculation on one or another European national currency that had ensued after the end of the Bretton Woods monetary system, led governments to trust Finance Ministers, Central Bankers and consultant technocrats in general to negotiate many of the key provisions for Maastricht and the EU as well of course of the formation of the single currency, the Euro.

Thus, as Dyson and Featherstone have shown, Italian leaders let technocrats negotiate on behalf of Italy, fearing the dysfunctionality of Italy's party politics might disrupt the creation of a more united Europe. ${ }^{19}$ That many of the technocrats involved in building the EU - and global neoliberalism - were themselves ensconced in elected government ministries and agencies helped this process along: Michel Camdessus, who would later become head of the IMF was Mitterand's Treasury Director, and Jacques Delors, who later led the European Commission, was Finance Minister. As Mitchell and Fazi note, these two played important roles in convincing Mitterand to accept austerity in the first place. Now they would be able to apply the lessons of neoliberal economics to the global south and to Europe, respectively. Giscard D'Estaing instead would later show up again as chair of the committee to write the EU Constitution, which, after being rejected in 2005 by voters in France and the Netherlands, became the Lisbon Treaty and was implemented largely intact anyway, ratifying the neoliberal orthodoxy as a basis of EU institutions. Still seeking political influence, French politicians saw currency union as a means to have a vote and a voice in what had already become an effective Bundesbank-Deutschemark zone. But the German insistence on Central Bank autonomy and technocrats' arguments that the issues involved were largely technical and too difficult for non-experts led the actual negotiations over the Euro to be carried out by central bankers. As a group, as we have seen, these had a political interest in expanding their power and influence over and against the power and influence of competing groups such as elected officials and parties, organized labor (which was completely excluded from all negotiations over European economic unity and the common currency), and electorates. As Mitchell and Fazi note, "What eventually allowed the 'nine horses' to be harnessed together into the monetary union was not a diminution in the Franco-German rivalry, but a growing homogenization of the economic debate."20

One way to see the pre-2008 rise to hegemony of neoliberalism in Europe, then, is as a misguided and indeed failed attempt by elected governments to restore their abilities to govern in the face of the power of organized labor, under the new conditions of the post-Bretton Woods, post-Oil Crises world economy. The defeat of the Mitterand Government was seen as a cautionary tale, and its own recourse to Europe as a solution inadvertently led to creating institutions in which the new neoliberal order could plant its shallow but powerful roots. When the 2008 crisis happened, and a wave of government spending to sustain banks took place, the power of technocrats remained in place at the ECB and Commission as well as at a strengthened IMF (whose authority had previously been almost completely stripped by the global movements against debt and structural adjustment). The German government's own geopolitical ambitions now coincided with maintaining the Euro at all costs, and with the interests of the technocrats, and its export economy favored the free trade regime of neoliberal capitalist interests. When the Greek crisis hit, as Yanis Varoufakis has made clear ${ }^{21}$, it was a crisis for French and German banks that were the holders of Greek public debt, and saving those banks became paramount to both governments. Doing so meant ruining the Greek people and economy, and soaking the taxpayers and workers of the rest of Europe to "bail out" Greece, when in fact the money quickly passed through Greek government hands back to the German and French creditors. The IMF's bailout similarly exploited funds from workers and small businesses around the world to pay the creditors, with Greece merely as a conduit. As John Raulston Saul argues, what the technocracy is expert at is managing problems, and the Euro-debt crisis, and austerity are ideal to its expertise and so functional to its power and influence, at the expense of workers, small business and artisans, communities and national populations, that is to all those with an interest in democratic self-government. ${ }^{22}$ Those countries, like Sweden, which were latecomers to the neoliberal party, have merely accelerated their reversal of policy, imposing newfound orthodoxies on bewildered populations at an even less absorbable rate. ${ }^{23}$ 


\section{Protagoras Versus Socrates Revisited}

Hermes: "Am I to deal out aidos (sense of shame) and dike (knowledge of justice) as the other arts have been dealt out, one man possessing the medical arts is able to treat many ordinary men, and so with the other craftsmen"?

Zeus: "To all. Let all have their share. For cities cannot be formed if only a few possess aidos and dike."

- From story told by democratic Protagoras in his debate with technocratic Socrates as recounted in Plato's Dialogue "Protagoras". 24

What technocrats are unable to do is solve problems. For that, one must leave the technocratic neoliberal normative system that sees all activity through the lens of economics, imposes neoliberal and neoclassical economics as the only school permissible ${ }^{25}$ and widen the debate to include other values, the values of democratic polities with all of their diversity, and complexities. Europe, a unified Europe, might have been the solution at long last to the millennia-old problem facing the nations of the Continent that mobile capital has been able to dictate to them the conditions under which it would help them to power; a means, that is, to end national competition with each other for power and influence. Instead it has become the main instrument for holding them fast by neoliberal chains. Is it possible that it will be in the United States, not in socialism's historic home of Europe, that the democratic socialism of the $21^{\text {st }}$ Century will arise, and if so, perhaps its coming could signal, as Marx once hoped the US Civil War would, the clarion call for change in Europe as well?

Or is the new nationalism sweeping Europe (and not only Europe) the distorted, even dialectical form of a necessary correction, placing power back into the hands of elected governments and polities, even if at first into the hands of rather despicable actors (Salvini, Orbàn, Kacsinski etc.))? Either way, it is doubtful that so despised a normative system ${ }^{26}$ and set of economic institutions as neoliberalism in its fully technocratic vestments can long rule a Continent whose diversity of national histories and whose long struggle for a decent life is now being strangled by a homogenizing and dysfunctional set of economic axioms applied to the real world by a set of trained bureaucratic experts lacking in vision, without pity or any sense of fairness that is not market-based.

Like it or not, Europe's greatest accomplishments: the medieval city-republics, the Renaissance, the Reformation, Elizabethan England, even, despite its universalist pretensions the French Enlightenment, the Romantics, Democracy, even Socialism, and of course the golden decades after the Second World War through the 1980s, all occurred or came about not during the periods of greater institutional unity (the Roman Empire, the Medieval Church, Napoleonic Era, Hapsburg Empire, or Nazi occupation) but when the various societies making up the diverse Continent were able to each find their own paths to societal happiness and self-determination. The neoliberal straightjacket will be thrown off, one way or another. Those who seek to maintain the neoliberal status quo at all costs, in the name of economic logic or of technocratic expertise, will merely insure that what comes next will, instead of being benign and enhancing of human possibilities, take a distorted and mangled form as are those morbid symptoms (as Gramsci called them) now appearing. If history is any guide, it is unlikely that it is to economists as a profession that we should look for alternatives, but rather to the full cultural and political resources of the populations of Europe.

\section{ACKNOWLEDGEMENTS}

I thank Jon Rynn for presenting the paper in person on my behalf as I was unable to be personally present at the URPE section of the EEA Conference March 2, 2019; I am grateful to Engelbert Stockhammer and to Riccardo Bellofiore for providing me with advice and guidance toward sources, and to John McDermott for comments on an earlier draft of this paper. 


\section{ENDNOTES}

1. Mark Leonard, Why Europe Will Run the 21st Century London, Fourth Estate, 2011; Jeremy Rifkin, The European Dream TargerPerigee 2005; Susan George, Another World Is Possible, If...” Verso, 2004.

2. Werner Sombart, Why Is There No Socialism In the United States? PalgraveMacmillan, 1976

3. Sombart, Why Is There No Socialism; Louis Hartz, The Liberal Tradition in America Harvest Books, 1991; Frederick Jackson Turner, The Frontier in American History, CreateSpace Independent Publishing Platform, 2017.

4. David Ost, The Defeat of Solidarity: Anger and Politics in Post-Communist Poland Cornell University Press, 2006.

5. John Raulston Saul, The Collapse of Globalism and the Reinvention of the World Atlantic Books 2005.

6. See Karl Marx, Capital, Vol. 1 Vintage 1977; Giovanni Arrighi, The Long Twentieth Century, Verso 1994.

7. See also Judith Stein, Decisive Decade: Re-evaluating the Seventies Yale University Press, 2010, and Benjamin Waterhouse, Lobbying America: The Politics of Business from Nixon to NAFTA Princeton University Press, 2015 for fuller discussions of the role of capitalists as an organized class in the shift to neoliberalism.

8. Ralph Miliband, Marxism and Politics Oxford University Press 1978.

9. William Mitchell and Thomas Fazi, Reclaiming the State: A Progressive Vision of Sovereignty for a PostNeoliberal World Pluto Press, 2017

10. William Mitchell and Thomas Fazi, Reclaiming the State: A Progressive Vision of Sovereignty for a PostNeoliberal World Pluto Press, 2017.

11. Aled Davies, "The Evolution of British Monetarism, 1968-1979" Discussion Papers in Economic and Social History No.104, University of Oxford, 2012, pp.1, 5 and passim.

12. Quoted in Davies, "The Evolution" p. 5.

13. Max Weber, Economy and Society, University of California Press, Berkeley, 1978.

14. See Stephen Toulmin's brilliant ex position in Cosmopolis.

15. An excellent discussion of the mainly political, rather than economic objections to democracy in neoliberal thought and practice is found in Engelbert Stockhammer, "The Eurocrisis and Contradictions of Neoliberalism in Europe" Economic Discussion Papers 2013-2, Kingston University London December 2013.

16. This comment is analogous to and is informed by the analysis by John McDermott in Restoring Democracy to America, that the movements of the 1960s and 1970s went beyond what governments and elites could concede without substantially radicalizing the structures of power in society as a whole, leading to a revolt of the elites and an end to the tacit alliance that for a century had expanded possibilities for democratization.

17. Franco Modigliani and Tommaso Padoa-Schioppa, "The Management of an Open Economy with 100\% Plus Wage Indexation" Essays in International Finance, No.130 (December 1978).

18. See the discussion in Monica Prasade, "Why is France so French? Culture, Institutions and Neoliberalism" The American Journal of Sociology, Vol. 111, No. 2 (September 2005), pp. 357-407

19. Kenneth Dyson and Kevin Featherstone, 1996 "Italy and EMU as a 'Vincolo Esterno': Empowering the Technocrats, Transforming the State" South European Society and Politics 1:2 272-299.

20. Mitchell and Fazi, Reclaiming the Nation p.90.

21. Yanis Varoufakis, Adults in the Room The Bodley Head London, 2018

22. See John Raulston Saul, The Collapse of Globalism Atlantic Books, 2005.

23. Goran Therborn, "Twilight of Swedish Social Democracy” New Left Review 113 Sept- Oct 2018

24. The debate between the democrat Protagoras and the technocrat Socrates is illuminated by the discussions in Ellen Meiksins Wood, Peasant, Citizen and Slave Verso 2015, and I.F. Stone, The Death of Socrates Random House, 1989.

25. As the authors of The Econocracy have shown. Joe Earle, Cahal Moran, Zach Ward-Perkins, The Econocracy: on the perils of leaving economics to the experts Penguin, 2017.

26. Riccardo Bellofiore and Giovanna Vertova, Ai confini della docenza: per una critica dell'Università Accademia University Press 2018, and Kate Nash, Neoliberalisation, the Universities and the Values of Bureaucracy The Sociological Review 2019, Vol. 67(1) 178-193. 